3. Krikunov M. Maibutnie universytetu: misiia mozhlyva, yakshcho vona sformulovana. URL: http://nus.org.ua/articles/majbutnyeuniversytetu-misiya-mozhlyva-yakshho-vona-sformulovana/.

4. Lukov V. Myrovaia unyversytetskaia kultura. Znanye. Ponymanye. Umenye. 2005. № 3. S. 32-33.

5. Pokidina V. Universytety ta biznes: mizhnarodnyi dosvid spivpratsi ta perspektyvy dlia Ukrainy. Proekt «Populiarna ekonomika: tsina derzhavy». № 41.24 travnia 2016 r. URL: http:// case-ukraine.com.ua.

6. Ryzhak L. Samodostatnia osoba yak ideal postneklasychnoi modeli osvity. Visnyk Lvivskoho un-tu. Seriya : filosofski nauky. 2006. Vyp. 9. S. 12-24.

7. Sovsun I. Ideia universytetu ta iii istorychni metamorfozy. URL: https://medium.com/@inna.sovsun.

8. Pawlowski Krzysztof. Rediscovering higher education in Europe. Bucharest : UNESCO-CEPES, 2004. 146 p.

\title{
Hnativ Z. Ya. University as strategic resource for society development: institution and transformation
}

Problems in the formation of individuality, the implementation of the inclinations and internal reserves of each person, as well as aesthetic, integral, leadership development is given increasing importance in modern scientific developments. We make high rates on the aesthetic-emotional development of the individual in modern higher education; we are turning to the transformation of the intellectual center, where the formation of specialists, intellectuals, elites, namely, the university, takes place.

There are many educational problems in Ukraine related to the prospects of building a world-class university. However, the current scientific potential of leading specialists in the process of reforming university education is making a great effort to bring higher education in line with current world standards, seeking answers to topical questions, realizing strategic objectives, overcoming obstacles to the optimal ways of developing both higher education and cultural -the educational level of society as a whole.

For our part, we raise the question of harmonizing the cultural and educational space, the place of aesthetic education in high school, pointing out its extremely necessary need, since, in the formation of a professional in any field, the issues of morality and spirituality, the filling of the beauty of the inner and outer world, humanity are important, as Prof. Skotny noted, first of all «the main thing is to be a Human».

The article covers issues of the essence, concept, model, idea of the university, on which the present and future depend. Attention is drawn to the peculiarities of American and European universities, whose competition in the early twentieth century led to the launch of the Lisbon and Bologna processes. The transformational processes in modern higher education, ways to overcome the crisis, the importance of consolidating the intellectual elite, etc. are analyzed (for example, the creation of a joint project of representatives of Ukrainian business, politics and the public sector, an independent analytical center of the Ukrainian Institute for the Future (UIF)).

Key words: higher education, university, university model, transformation, society, intellect, society, aesthetic education.

УДК 378.147:005.6]:614.253.5

DOI https://doi.org/10.31392/2311-5491/2019-69.10

Гордійчук $C$. В.

\section{ЗАБЕЗПЕЧЕННЯ ЯКОСТІ ОСВІТНЬОЇ ДІЯЛЬНОСТІ ЗАКЛАДУ МЕДИЧНОЇ ОСВІТИ ШЛЯХОМ ВПРОВАДЖЕННЯ ІНФОРМАЦЙНО-КОМУНІКАЦІЙНИХ ТЕХНОЛОГІЙ}

Стаття присвячена проблемі забезпечення якості освітньої діяльності та сучасному стану впровадження інформаційно-комунікативних технологій у підготовці майбутніх медичних фахівців. Методологія дослідження була адаптована до роботи зі студентами периих та четвертих курсів спеиіальності 223 «Медсестринство», що здобувають освітньо-кваліфікаційний рівень молодшого спеціаліста, а також із здобувачами освітнього ступеню бакалавр та магістр, ще навчаються на умовах ступеневої медичної освіти.

Проведено аналіз науково-методичних джерел та здійснено соиіологічне опитування респондентів для визначення системності застосування викладачами закладу медичної освіти інформаційно-комунікаційних технологій у освітньому процесі; інформаційно-комунікативних технологій як елементу підвищення якості освітньої діяльності для здобувачів медичної освіти; впливу інформаційно-комунікативних технологій на формування професійних компетентностей у майбутніх медччних сестер. Отримані під час дослідження анкетні дані були проаналізовані та на основі результатів соиіологічного дослідження було побудовано модель впровадження інформачійно-комунікачійних технологій у підготовиі майбутніх медичних сестер.

Науковою новизною дослідження стало обтрунтування стану використання IКT та подальшого вдосконалення інноваційних технологій у процесі навчання майбутніх медичних фахівців. Одержані результати впроваджено у підготовку медччних сестер КВНЗ «Житомирський медичний інститут» Житомирської обласної ради.

Серед загальних висновків, щзо зроблені за результатами дослідження, необхідно визначити те, щзо забезпечення якості освітнього процесу є пріоритетним завданням діяльності закладів медичної освіти. Підкреслено важливе значення інформаційно-комунікаційних технологій в освітньому проиесі, а також необхідність вдосконалення сьогоднішнього стану системи використання IКТ та подальшого впровадження інноваційних технологій у процесі навчання майбутніх медичних фахівиів.

Ключові слова: якість, медична освіта, інформаційно-комунікаційні технології.

Якість освіти - це ряд системно-соціальних якостей і характеристик, які визначають відповідність системи освіти прийнятим вимогам, соціальним нормам, державним освітнім стандартам [2]. Отримання якісної освіти безпосередньо залежить від якості самих вимог (цілей, стандартів і норм), якості ресурсів (про- 
грами, кадровий потенціал, контингент абітурієнтів, матеріально-технічне забезпечення, фінанси і т.д.) та якості освітніх процесів (наукова та навчальна діяльність, управління, освітні технології), які безпосередньо забезпечують підготовку фахівців [1]. Нині відбувається накопичення досвіду, пошук шляхів підвищення якості навчання і нових форм використання інформаційно-комунікаційних технологій у різних освітніх процесах [5], зокрема, при підготовці майбутніх медичних сестер. Модернізація та забезпечення якості медичної освітньої діяльності [4] шляхом сучасного розвитку інформаційних технологій та застосування інформаційно-комунікаційних (далі - IКТ) засобів, а також ІКТ-методів навчання дасть можливість учасникам освітнього процесу (студентам, викладачам) отримувати можливість самостійно обирати програми та модулі організації освітньої діяльності, використовувати як традиційну систему освіти, так і безперервну освіту на основі IКТ, що допоможе підвищувати якість надання освітніх послуг у медичних інститутах, коледжах, училищах, які здійснюють підготовку медичних сестер, акушерок, парамедиків (фельдшерів) [3].

Проблемам управління якістю освіти в сучасних ринкових умовах присвячено роботи В. Бондаря, I. Булах, С. Гордійчук, Г. Дмитренка, Г. Єльникової, Л. Калініної, Т. Лукіної, В. Маслова, В. Олійника, В. Радченко, Т. Сорочан. Окремі аспекти впровадження інформаційно-комунікаційних технологій у освітній процес досліджували А. Андрєєва, В. Бикова, М. Жалдака, С. Сисоєва, О. Спірина, П. Стефаненко та інші.

Метою статті $\epsilon$ аналіз системності застосування інформаційно-комунікаційних технологій у освітньому процесі та обгрунтування моделі впровадження ІКТ-технологій у підготовку майбутніх медичних сестер.

На початковому етапі педагогічного дослідження особливо важливим є збір даних щодо фактичного стану досліджуваної проблеми у педагогічній практиці. Основними практичними методами збору початкових даних є спостереження, бесіди, інтерв’ю та анкетування. Нами було розроблено анкету, метою якої було отримання інформації щодо використання інформаційно-комунікаційних технологій в освітньому процесі підготовки медичних сестер. Анкета складалась з 25 запитань, що були розділені на 3 кластери: системність застосування викладачами закладу медичної освіти інформаційно-комунікаційних технологій у освітній процес; інформаційно-комунікативні технології як елемент підвищення якості освітньої діяльності для здобувачів медичної освіти; вплив інформаційно-комунікативних технологій на формування професійних компетентностей у майбутніх медичних сестер.

Дослідження проводилось на базі КВНЗ «Житомирський медичний інститут» Житомирської обласної ради, було отримано відповіді 200 респондентів (70 осіб (35\%) - студенти І року навчання та 70 осіб (35\%) студенти IV року навчання відділення «Сестринська справа», а також 60 осіб (30 \%) - студенти освітнього ступеня магістр та бакалавр кафедри «Сестринська справа»).

За результатами анкетування за першим кластером нами було з'ясовано, що, на думку студентів, системність застосування викладачами закладу медичної освіти інформаційно-комунікаційних технологій у освітній процес не залежить від кваліфікаційного рівня викладача (79 \% респондентів) та 21 \% студентів вважають, що частково залежить. Також, 40 \% здобувачів медичної освіти підкреслили системність застосування інформаційно-комунікаційних технологій на лекційних та практичних заняттях науково-педагогічними та педагогічними працівниками; 30 \% зазначили періодичність використання IКТ технологій викладачами закладу та 30\% відмітили відсутність практики застосування інформаційно-комунікаційних технологій педагогічними працівниками під час аудиторних занять. Здобувачі вищої освіти, які прийняли участь в опитуванні, зауважили, що найбільш привабливою формою засвоєння нового матеріалу є: пояснення викладача під час проведення лекційних занять та занотовування необхідного матеріалу (12 \% студентів I курсу; 5 \% студентів IV курсу та 4 \% здобувачів освітнього ступеня бакалавр та магістр); представлення матеріалу викладачем з використанням інформаційно-комунікаційних технологій (31% студентів I курсу; 43 \% студентів IV курсу та 51 \% здобувачів освітнього ступеня бакалавр та магістр); опанування нового матеріалу шляхом проведення самостійного дослідження 3 подальшим оприлюдненням результатів (27 \% студентів I курсу; 7 \% студентів IV курсу та 3 \% здобувачів освітнього ступеня бакалавр та магістр); розв’язання проблемних питань (застосування проблемно-орієнтованого методу) за допомогою викладача (18\% студентів I курсу; 27 \% студентів IV курсу та 14 \% здобувачів освітнього ступеня бакалавр та магістр); самостійно окреслювати проблему, знаходити шляхи ії розв'язання, робити самостійні висновки (4 \% студентів I курсу; $2 \%$ студентів IV курсу та 9 \% здобувачів освітнього ступеня бакалавр та магістр); приймати активну участь у реалізації творчих завдань та освітніх проєктах із використанням IКТ (8 \% студентів I курсу; 17 \% студентів IV курсу та 19 \% здобувачів освітнього ступеня бакалавр та магістр). Окрім того, 30,8 \% студентів підкреслили, що викладачі систематично застосовують ІКТ під час проведення підсумкового контролю; 42,2 \% зауважили періодичне використання інформаційно-комунікаційних технологій під час іспитів, заліків тощо; 27 \% студентів, які приймали участь в опитуванні, визначили відсутність досвіду реалізації контролю знань за допомогою інформаційно-комунікаційних методів та технологій.

Аналізуючи відповіді студентів з питань, які були віднесені до 2-го кластеру, нами було відмічено, що основними формами застосування ІКТ технологій у освітньому процесі є: підготовка навчальних матеріалів за допомогою комп'ютерної техніки (37 \% студентів I курсу; 16 \% студентів IV курсу та 9\% здобувачів освітнього ступеня бакалавр та магістр); пошук інформаційних джерел у мережі Інтернет (35 \% студентів I курсу; 39 \% студентів IV курсу та 41 \% здобувачів освітнього ступеня бакалавр та магістр); створення відеороликів та презентацій за результатами власних досліджень (28 \% студентів I курсу; 45 \% студентів 
IV курсу та 50 \% здобувачів освітнього ступеня бакалавр та магістр). Відповіді на питання «Для підвищення якості освітньої діяльності, яким формам оцінювання знань, умінь, навичок Ви надали б перевагу?» розділились так: лише 5\% серед студентів IV року навчання, 7 \% серед студентів I року навчання та 3 \% студентів 3 освітнім ступенем магістр та бакалавр - надали перевагу відповіді «усне опитування». $11 \%$ студентів I курсу навчання, 8 \% студентів IV року навчання та 6 \% студентів з освітнім ступенем магістр та бакалавр серед пріоритетів визначили дискусію. Розв'язанню конкретних ситуаційних завдань та застосування кейсів надали перевагу 22 \% студентів I року навчання, 14 \% студентів IV року навчання та 4 \% студентів 3 освітнім ступенем магістр та бакалавр. Більша частина здобувачів медичної освіти (48 \% студентів I року навчання, $54 \%$ студентів IV року навчання та 66 \% студентів з освітнім ступенем магістр та бакалавр) відмітили, що комп’ютерний контроль $є$ найбільш адекватною формою визначення рівня сформованих компетентностей. Решта респондентів (12\% студентів I року навчання, $19 \%$ студентів IV року навчання, $21 \%$ студентів освітнього ступеня магістр та бакалавр) зауважили, що лише творчі роботи є найкращою формою оцінювання знань, умінь та навичок майбутніх медичних сестер.

Також нами з'ясовано, що основними дієвими формами оцінювання якості самостійної роботи студентів, на думку здобувачів медичної освіти, є узагальнення результатів самостійних досліджень у вигляді презентацій та відеороликів (33 \% студентів I року навчання, 60 \% студентів IV року навчання та $46 \%$ студентів освітнього ступеня магістр та бакалавр); представлення самостійної роботи із заданої теми у вигляді реферату (41 \% студентів I року навчання, 8 \% студентів IV року навчання та $2 \%$ студентів освітнього ступеня магістр та бакалавр); підготовка тез за результатами проведеного самостійного дослідження (3\% студентів I року навчання, $26 \%$ студентів IV року навчання та $45 \%$ студентів освітнього ступеня магістр та бакалавр); представлення результатів самостійної робити у вигляді усної доповіді (23 \% студентів I року навчання, 8 \% студентів IV року навчання та 5 \% студентів освітнього ступеня магістр та бакалавр). Окрім того, майбутні медичні сестри, які здобувають ступеневу медсестринську освіту, зауважили, що використання викладачем технічних засобів для представлення візуальної інформації на заняттях підвищує рівень сприйняття та запам’ятовування.

Отримані у ході опитування відповіді респондентів, що були віднесені до 3-го кластеру надали можливість визначити вплив інформаційно-комунікативних технологій на формування професійних компетентностей у майбутніх медичних сестер. Так було з'ясовано, що на думку здобувачів медичної освіти, пріоритетними змінами, які б сприяли підвищенню якості професійної підготовки медичних сестер є такі: збільшення частоти використання викладачами на заняттях сучасних інноваційних технологій (32\% студентів I року навчання, 43 \% студентів IV року навчання та $41 \%$ студентів освітнього ступеня магістр та бакалавр); підвищення рівня комунікації та толерантності серед учасників освітнього процесу (викладач, студент, адміністрація закладу) (18\% студентів I року навчання, $16 \%$ студентів IV року навчання та $16 \%$ студентів освітнього ступеня магістр та бакалавр); систематичне підвищення кваліфікації викладачів шляхом участі у тренінгах, семінарах, воркшопах, що сприятиме посиленню якості педагогічної майстерності науковопедагогічних та педагогічних працівників (12\% студентів I року навчання, $9 \%$ студентів IV року навчання та $12 \%$ студентів освітнього ступеня магістр та бакалавр); постійне удосконалення матеріально-технічної бази закладу медичної освіти (15 \% студентів I року навчання, 12 \% студентів IV року навчання та $9 \%$ студентів освітнього ступеня магістр та бакалавр); періодичний перегляд освітніх програм (8 \% студентів I року навчання, $6 \%$ студентів IV року навчання та $6 \%$ студентів освітнього ступеня магістр та бакалавр); систематичний зворотній зв'язок із усіма учасниками освітнього процесу (15\% студентів I року навчання, 14 \% студентів IV року навчання та $16 \%$ студентів освітнього ступеня магістр та бакалавр). Особливістю підготовки здобувачів освіти у галузі знань 22 «Охорона здоров’я», зокрема, спеціальності 223 «Медсестринство» $\epsilon$ те, що для визначення рівня сформованості загальних та спеціальних компетентностей, освітнім стандартом передбачено проведення ліцензійного інтегрованого іспиту «Крок». У кожного закладу медичної освіти є свої технології підготовки здобувачів освіти до процедури ліцензійного випробування, однак. найпоширенішою практикою є створення внутрішнього інформаційного середовища, яке містить навчальний, методичний, практичний, науковий контент. Тому нами було з'ясовано рівень задоволеності студентів функціонування такої системи, частоту використання інших програм, що сприяють підготовці до єдиного кваліфікаційного комплексного іспиту, а також яким інформаційним контентом користуються студенти для підготовки до навчальних занять та оцінювання якості набуття знань, умінь і навичок.

Результати, що отримані у ході дослідження, свідчать про те, що більшість респондентів серед студентів IV року навчання (56 \%) та здобувачів освітнього ступеня бакалавр та магістр (58 \%) вказали, що для підготовки до навчальних та практичних занять частіше використовують всесвітню систему сполучених комп'ютерних мереж - Інтернет. Водночас, більшість студентів І року навчання (49\%) зауважили, що систематично користуються послугами бібліотеки закладу освіти.

Нами визначено, які сучасні соціальні мережі у процесі навчання використовують здобувачі медичної освіти. Встановлено, що 15\% студентів I року навчання, 27 \% студентів IV року навчання та $26 \%$ студентів освітнього ступеня магістр та бакалавр систематично використовують інформацію 3 Instagram; для 13\% студентів I року навчання, 29 \% студентів IV року навчання та $28 \%$ студентів освітнього ступеня магістр та бакалавр, найбільш привабливим для отримання необхідного матеріалу є Facebook; 49\% студентів I року навчання, $23 \%$ студентів IV року навчання та 21\% студентів освітнього ступеня магістр та бакалавр у про- 
цесі підготовки до аудиторних та практичних занять використовують електронну пошту; решта респондентів (23\% студентів I року навчання, $21 \%$ студентів IV року навчання та $25 \%$ студентів освітнього ступеня магістр та бакалавр) користуються іншими соціальними мережами та мобільними додатками: Viber, Whats App, Google Translate, Google Classroom, Google Chrome, QR-код тощо.

Для забезпечення якості освітньої діяльності на інституційному рівні та підвищення рівня позитивного впливу на результати єдиного кваліфікаційного комплексного іспиту, закладам медичної освіти необхідно бути обізнаними щодо інформаційного контенту, яким користуються студенти під час підготовки до оцінювання якості набуття знань, умінь та навичок. За результатами опитування було з'ясовано, що 15 \% студентів I року навчання, 21 \% студентів IV року навчання та 18 \% студентів освітнього ступеня магістр та бакалавр для підготовки до підсумкового модульного контролю та кваліфікаційного іспиту використовують інтегровану систему пакету програм «Колоквіум», яка дає змогу виконувати завдання тестів у різних комбінаціях i режимах тестування; 45 \% студентів I року навчання, 12 \% студентів IV року навчання та $14 \%$ студентів освітнього ступеня магістр та бакалавр вважають, що найкращою формою підготовки до інтегрованих іспитів є систематичне опрацювання кожного тестового завдання під контролем викладача; $31 \%$ студентів I року навчання, 9 \% студентів IV року навчання та 7 \% студентів освітнього ступеня магістр та бакалавр, зауважили, що лише самостійне опрацювання інформаційного контенту надає найкращі результати аудиту якості формування загальних та спеціальних компетентностей у майбутніх медичних сестер; 19 \% студентів I року навчання, 58 \% студентів IV року навчання та $61 \%$ студентів освітнього ступеня магістр та бакалавр підкреслили необхідність систематичного опрацювання банку тестових завдань, що знаходяться у вільному доступі на вебсторінці ДУ «Центр тестування при МОЗ України».

Проведений аналіз результатів констатувальної частини дослідження дав змогу визначити необхідність створення моделі впровадження інформаційно-комунікаційних технологій у підготовку майбутніх медичних сестер. Мета моделі - забезпечення якості освітньої діяльності шляхом підвищення рівня формування загальних та спеціальних компетентностей майбутніх медичних сестер під час проєктування освітнього процесу засобами ІКТ-технологій. Модель представлена чотирма основними блоками: концептуально - цільовий; змістовний; діяльнісний; результативний. В основі концептуального блоку розміщені сучасні педагогічні ідеї щодо підвищення рівня якості освітньої діяльності підготовки майбутніх медичних сестер; модернізація та вдосконалення системи професійної підготовки медичних кадрів, зокрема у медичних коледжах та училищах; оптимізація освітнього процесу у відповідності до європейських стандартів підготовки медичних спеціалістів. Серед потенційних можливостей визначено вдосконалення та систематичне застосування інформаційно-комунікаційних технологій при формуванні фахових компетентностей у майбутніх медичних сестер; розміщення ресурсного забезпечення навчальної компоненти освітнього процесу; використання ІКТ як засобу самостійної підготовки. Змістовний блок характеризує напрями та інструменти забезпечення якості освітньої діяльності шляхом провадження інформаційно-комунікаційних технологій у підготовку майбутніх медичних сестер. Діяльнісний блок визначає етапи провадження (визначення цілій, модернізацію системи управління освітньої діяльності підготовки медичних сестер, реалізацію проєкту освітнього процесу та оцінку результатів такого провадження); форми (традиційні та інноваційні); технології проєктування (комп'ютерне програмне забезпечення, Інтернет і мультимедійні технології, системне комп'ютерне тестування тощо). Результативний блок визначає вимоги до рівня сформованості загальних та спеціальних компетентностей шляхом провадження інформаційно-комунікаційних технологій у підготовці майбутніх медичних сестер; критерії сформованості компетентностей (мотиваційний, когнітивний, діяльнісний, рефлексивний).

Висновки. Забезпечення якості освітнього процесу є пріоритетним завданням діяльності закладів медичної освіти, оскільки від рівня сформованості загальних та фахових компетентностей випускників залежить рівень надання медичної допомоги населенню країни. За результатами проведеного соціологічного дослідження нами виявлено, що серед респондентів 82 \% студентів I року навчання, 87 \% студентів IV року навчання та 93 \% здобувачів освітнього ступеня магістр і бакалавр вказали на важливість значення інформаційно-комунікаційних технологій в освітньому процесі, необхідність вдосконалення сьогоднішнього стану системи використання ІКТ та подальшого впровадження інноваційних технологій в процесі навчання майбутніх медичних фахівців. Впровадження розробленої моделі використання ІКТ у процесі навчання майбутніх медичних сестер надають можливість підвищити рівень забезпечення якості освітньої діяльності при підготовці кадрів для системи охорони здоров’я України.

\section{Використана література:}

1. Борисова Є. Е. Якість освіти і місце вищої школи в суспільстві. Альма-матер. 2003. № 11. С. $27-33$.

2. Гордійчук С. В. Забезпечення якості освітньої діяльності за участю студентів у вищому медичному навчальному закладі. Вісник Житомирського державного університету ім. I. Франка. 2016. Вип. 3 (85). С. 37-42.

3. Гордійчук С. В. Застосування інтегрованої інформаційної системи управління освітнім процесом у медичному коледжі. Педагогічні інновації: ідеї, реалії, перспективи: зб. наук. пр. 2016. Вип. 2 (17). С. 86-95.

4. Гордійчук С. В. Якість як пріоритетний напрям освітньої діяльності медичного навчального закладу. Вісник Луганського національного університету ім. Т. Шевченко (педагогічні науки). Вип. 6 (303). Жовтень, 2016. С. 100-107.

5. Ставицька I. В. Інформаційно-комунікаційні технології в освіті. URL: http://confesp.fl.kpi.ua/ru/node/1103. 
References:

1. Borysova Ye. E. Yakist osvity i mistse vyshchoi shkoly v suspilstvi. [Quality of education and the place of higher education in society]. Alma-mater. 2003. № 11. S. 27-33.

2. Gordiichuk S. V Zabezpechennia yakosti osvitnoi diialnosti za uchastiu studentiv u vyshchomu medychnomu navchalnomu zakladi [Ensuring the quality of educational activities with the participation of students in a higher medical school]. Visnyk Zhytomyrskoho derzhavnoho universytetu im. I. Franka. 2016. Vyp. 3 (85). S. 37-42 (ukr).

3. Gordiichuk S. V. Yakist yak priorytetnyi napriam osvitnoi diialnosti medychnoho navchalnoho zakladu. [Quality as a priority direction of educational activity of a medical educational institution]. Visnyk Luhanskoho natsionalnoho universytetu im. T. Shevchenko (pedahohichni nauky). 2016. № 6 (303). October. S. 100-107 (ukr).

4. Gordiichuk S. V. Zastosuvannia intehrovanoi informatsiinoi systemy upravlinnia osvitnim protsesom u medychnomu koledzhi. [Application of an integrated information management system for educational process in a medical college]. Pedahohichni innovatsii: idei, realii, perspektyvy : zb. nauk. pr. № 2 (17). S. 86-95 (ukr).

5. Stavytska I. V. Informatsiino-komunikatsiini tekhnolohii v osviti. [Information and communication technologies in education]. URL: http://confesp.fl.kpi.ua/ru/node/1103.

Hordiichuk S. V. Ensuring of the quality educational activities of the institution medical education through the introduction of information and communication technologies

The article is devoted to the problem of ensuring the quality educational activities and the current state of implementation information and communication technologies in the training of future medical professionals. The methodology of the research was adapted to work with students of the first and fourth courses of specialty 223 "Nursing», obtaining the educational qualification of a junior specialist, as well as those with a bachelor's and master's degree, studying in terms of grade medical education.

The analysis of scientific methodology and sources of poll respondents conducted to determine the systematic application of medical education teachers of ICT in the educational process; information and communication technologies as part of improving the quality of educational activities for candidates of medical education; the influence of information and communication technologies in formation of professional competence of future nurses. The questionnaire data obtained during the study were analyzed and basis the results of a sociological study, a model for the implementation of information and communication technologies in the training of future nurses was constructed.

The scientific novelty of the study was the substantiation of the state of using ICT and further improvement of innovative technologies in the process of training future medical professionals. The obtained results were implemented in the training of medical nurses of MHEI «Zhytomyr Medical Institute» Zhytomyr Regional Council.

Among the general conclusions made by a study it is necessary to determine that ensuring the quality of the educational process is a priority activity of the medical education institutions. Emphasis was placed on the importance of information and communication technologies in the educational process, and the necessity improvement the current state system of using ICT and further introduction of innovative technologies in training of future medical professionals.

Key words: quality, medical education, information and communication technologies.

УДК 378.147

DOI https://doi.org/10.31392/2311-5491/2019-69.11

Грицаєнко Л. М.

\section{САМОСТІЙНА РОБОТА СТУДЕНТІВ ЯК ПРОЦЕС САМОВИХОВАННЯ, САМОРОЗВИТКУ ОСОБИСТОСТІ МАЙБУТНІХ ПЕДАГОГІВ}

Досліджено роль самостійної роботи студентів у проиесі самовиховання, саморозвитку особистості майбутніх педагогів та розкрито актуальність теми на сучасному етапі. Розглянуто трактування понять «самовиховання» $i$ «саморозвиток» внаслідок зробленого аналізу використання ичих термінів у науковій літературі.

У статті проаналізовано самостійну роботу як складову освітнього процесу, яка сприяє формуванню в майбутніх педагогів високого ступеня самоосвіти, творчого ставлення до професійної діяльності; розвиває внутрішні резерви до самовдосконалення, самовиховання. Досліджено, щчо саморозвиток включає в себе самопізнання, самовизначення, творчу самореалізацію та самовибудовування особистості, самопроєктування. Вказано на чинники ефективної організації самостійної роботи здобувачів вищої освіти з метою досягнення майбутніми педагогами конструктивнокреативного - найбільш високого рівня самостійності під час виконання навчальних завдань. Доведено, щзо ефективна самостійна робота активізує освітню, дослідницьку, творчу, інноваційну, навчально-практичну діяльність кожного студента, поглиблюючи його знання, вміння, сприяє набуттю загальних і фахових компетентностей, визначених освітньою (освітньо-професійною, освітньо-науковою) програмою. Класифіковано самостійну роботу здобувачів вищої освіти за характерними ознаками.

Особлива увага приділена питанню академічної культури, професійної етики під час підготовки фахівиів, майбутніх педагогів, у закладах вищої освіти. Підкреслено на необхідності дотримання академічної доброчесності як науковими, науково-педагогічними, педагогічними працівниками, так $i$ здобувачами вищої освіти. У роботі зазначено, щчо моральноетичні иінності, задекларовані академічною спільнотою, є ключовими під час формування індивідуальності майбутніх педагогів як високопрофесійних фахівиів, здатних до самовиховання, мобільності, креативності, творчого саморозвитку.

Ключові слова: самостійна робота студентів, самовиховання, самовдосконалення, саморозвиток особистості майбутніх педагогів, ефективність організації самостійної роботи, здобувачі вищяої освіти, науково-педагогічні прачівники, академічна доброчесність. 